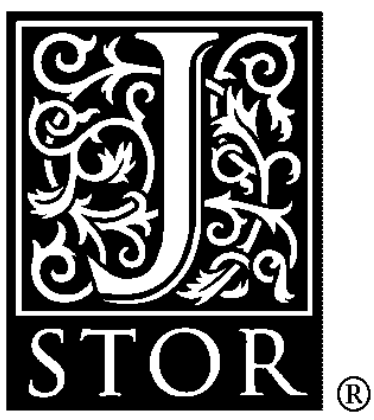

Viability, Electability, and Candidate Choice in a Presidential Primary Election: A Test of Competing Models

Author(s): Alan I. Abramowitz

Source: The Journal of Politics, Vol. 51, No. 4, (Nov., 1989), pp. 977-992

Published by: Cambridge University Press on behalf of the Southern Political Science Association

Stable URL: http://www.jstor.org/stable/2131544

Accessed: 22/05/2008 07:33

Your use of the JSTOR archive indicates your acceptance of JSTOR's Terms and Conditions of Use, available at http://www.jstor.org/page/info/about/policies/terms.jsp. JSTOR's Terms and Conditions of Use provides, in part, that unless you have obtained prior permission, you may not download an entire issue of a journal or multiple copies of articles, and you may use content in the JSTOR archive only for your personal, non-commercial use.

Please contact the publisher regarding any further use of this work. Publisher contact information may be obtained at http://www.jstor.org/action/showPublisher?publisherCode=cup.

Each copy of any part of a JSTOR transmission must contain the same copyright notice that appears on the screen or printed page of such transmission.

JSTOR is a not-for-profit organization founded in 1995 to build trusted digital archives for scholarship. We enable the scholarly community to preserve their work and the materials they rely upon, and to build a common research platform that promotes the discovery and use of these resources. For more information about JSTOR, please contact support@ jstor.org. 


\title{
Viability, Electability, and Candidate Choice in a Presidential Primary Election: A Test of Competing Models
}

\author{
Alan I. Abramowitz \\ Emory University
}

\begin{abstract}
Using data from an exit poll, this paper tests three models of voter decision making in a presidential primary: a simple candidate preference model, a bandwagon model, and an expected utility model. For both Republican and white Democratic primary voters, the data support the expected utility model. In choosing a candidate for their party's nomination, Republican and Democratic primary voters weighed electability in addition to their general evaluations of the candidates. Opinions about electability were, in turn, strongly influenced by perceptions of candidates' nomination prospects. Thus, viability had an important, but indirect, influence on voter decision making.
\end{abstract}

A

presidential primary election presents voters with a decision-making context which differs sharply from that of a general election or even another type of primary election. Perhaps the most important difference between presidential primaries and other types of primary elections is the fact that presidential primaries involve a series of separate contests spread over several months. Thus, the results of early contests, and the way these results are interpreted by the media, can influence voters in later contests. The New Hampshire primary and, in recent years, the Iowa precinct caucuses, have been considered especially significant in this regard because they are the first major events of the nominating campaign, and they receive extremely heavy coverage from the news media (Orren and Polsby 1987).

The sequential character of the presidential nominating process and the intense coverage which the news media devote to Iowa and New Hampshire have led to a great deal of speculation about the significance of momentum in presidential nominating campaigns. By winning or doing "better than expected" in Iowa and New Hampshire, a presidential candidate is said to gain momentum in subsequent contests. Thus, in 1976, Jimmy Carter, a little known ex-Governor of Georgia, finished first in Iowa and New Hampshire and went on to win the Democratic nomination. Eight years later, Gary Hart emerged from obscurity to challenge Walter Mondale for the Democratic

Journal of Politics, Vol. 51, No. 4, November 1989

(C) 1989 by the University of Texas Press 
nomination on the basis of a "surprisingly strong" second place finish in Iowa and a victory in New Hampshire.

Momentum is widely regarded as a major factor in the presidential nominating process. However, very little is known about why momentum is important or how it affects voter decision making in primary elections. In fact, there has been almost no systematic research on voter decision making in primaries. A few studies have analyzed citizens' pre-nomination candidate preferences. Bartels (1985), using data from the preconvention waves of the 1980 National Election Study, found a reciprocal relationship between citizens' expectations about the outcome of the nominating process and their candidate preference. The effect of expectations on preferences appeared to be strongest during the early stages of the nominating campaign.

Several recent studies have used data from the NES 1984 "rolling crosssection" survey to analyze pre-nomination candidate preferences. Abramowitz (1987), Bartels (1987), and Brady and Johnston (1987) all found that opinions about Gary Hart's and Walter Mondale's chances of winning the Democratic nomination had a significant influence on citizens' candidate preferences. Evaluations of Hart's nomination prospects and support for his candidacy both increased dramatically after his victory over Mondale in New Hampshire.

These findings appear to be consistent with the momentum hypothesis. However, the findings from the "rolling cross-section" survey may have reflected circumstances peculiar to the 1984 Democratic campaign - the fact that Gary Hart was largely unknown before the Iowa and New Hampshire contests may have magnified the impact of his early successes in those states. Moreover, none of these studies involved actual primary voters. Voters in a state holding a primary election may have a fuller opportunity to evalute the entire field of candidates than citizens in states where the candidates have not been campaigning. Direct exposure to the candidates and their campaigns may reduce the impact of momentum on primary voters.

\section{Three Models of Voter Decision Making in Presidential Primaries}

This paper will consider three models of voter decision making in presidential primaries. In each model, the dependent variable is the voter's candidate preference (Choice); the independent variables are the voter's overall evaluations of the major candidates (Candidate Evaluation), the voter's perceptions of the candidates' chances of receiving their party's nomination (Viability), and the voter's perceptions of the candidates' chances of winning the November election (Electability).

Although many other variables, including social background characteristics and policy preferences, may have affected voters' decisions in the primary, previous research on voting behavior in general elections has shown 


\section{FIGURE 1}

\section{Three Models of Voter Decision Making in Presidential Primaries}

A. Simple Candidate Choice Model

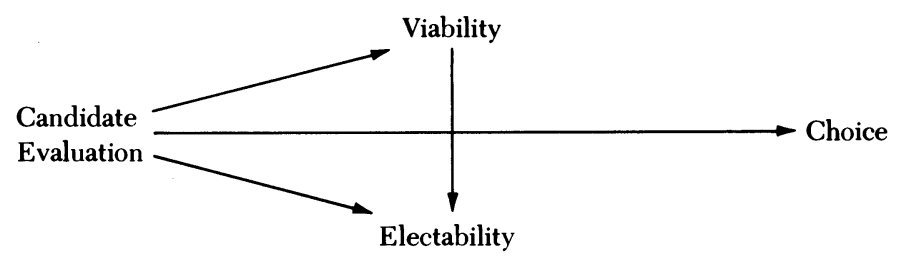

B. Bandwagon Model

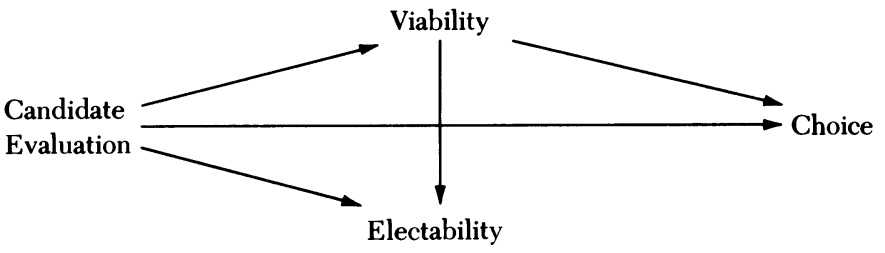

C. Expected Utility Model

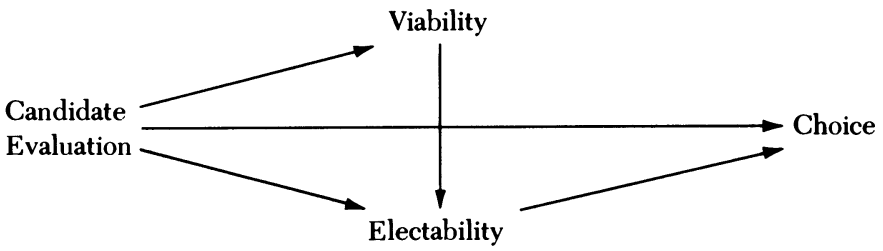

that the effects of these additional variables are almost entirely indirectmediated by evaluations of the candidates (Markus and Converse 1979; Markus 1982). There is no reason to expect candidate evaluations to play a less central role in voter decision making in primary elections. In fact, given the absence of partisan cues, candidates are probably even more salient in primaries than in general elections. As long as the effects of social background characteristics and policy preferences are mediated by candidate evaluations, then leaving these variables out of the analysis should not bias our estimates of the effects of the variables included in the model.

All three models assume that voters engage in wishful thinking-opinions about the candidates' chances of winning the nomination and the general election are based in part on voters' evaluations of the candidates. However, opinions about the candidates' nomination prospects should also reflect the 
results of earlier primaries and the media's interpretations of these results. All three models also assume that judgments about electability are influenced by voters' opinions about the candidates' nomination prospects. The most direct evidence that voters have available about a candidate's ability to wage an effective general election campaign is his or her ability to wage an effective pre-nomination campaign. Therefore, a candidate who does well or better than expected in the early primaries and caucuses will probably be viewed as more electable than a candidate who does poorly or worse than expected (see Aldrich 1980, 80-82).

The first model of voter decision making which will be considered in this paper is a simple candidate preference model. According to this model, opinions about the candidates' nomination chances and electability have no effects on voters' candidate preferences (see figure 1). Voters choose the candidate they evaluate most positively, and they also tend to assume that the candidate they like best is the one most likely to win the nomination and the general election. In this model, the results of earlier primaries and caucuses and media coverage of these results are important only if they influence voters' evaluations of the candidates.

The second model which will be considered in this paper is a bandwagon model. According to this model, opinions about the candidates' nomination chances directly influence voters' candidate preferences, but opinions regàrding electability have no effect on candidate preferences. The motivational assumption underlying this model is that voters want to be on the winning side in the nominating campaign because supporting a winner is intrinsically more enjoyable than supporting a loser. However, voters in this model are concerned exclusively about the nominating stage of the presidential selection process - they do not weigh electability as a separate criterion in choosing a candidate.

The third model which will be considered in this paper is an expected utility model. According to this model, primary voters weigh electability along with their evaluations of the candidates in making a choice. The assumption underlying this model is that primary voters are rational actors who seek to maximize their expected utility (Aldrich 1980, 80-82). Candidate evaluations, in this model, represent voters' assessments of the utility which they would obtain if the candidates were elected to the presidency. Therefore, these evaluations must be discounted by the subjective probability of each candidate winning the general election. The results of earlier primaries and caucuses are important primarily because they provide evidence about the candidates' chances of winning the general election.

\section{Data and Methodology}

The data used to test these three models of voter decision making come from an exit poll of presidential primary voters conducted in Dekalb County, 
Georgia, on March 8, 1988. Self-administered questionnaries were completed by 451 Democratic and Republican primary voters at 13 randomly selected precincts. Of the 451 respondents in the exit poll, 278 reported voting in the Democratic primary and 173 reported voting in the Republican primary. Despite the relatively small size of this sample of primary voters, the candidate preferences of the respondents in the exit poll came very close to matching the preferences of all Democratic and Republican primary voters in Dekalb County. More detailed information about the procedures used to conduct the exit poll and the validity of the sample are provided in appendix A.

For the purpose of analyzing voting behavior in a primary election, an exit poll has several major advantages over conventional survey techniques. It is possible to measure candidate preferences and other attitudes immediately after voters have cast their ballots, before these attitudes are contaminated by information about the results of the primary. Conventional survey techniques (either telephone or personal interviews) require that citizens be interviewed either before the primary, when they may not have reached a final decision, or after the primary, when their attitudes may have been modified by exposure to information about the results of the primary. This problem is especially serious when it comes to measuring voters' opinions about candidates' nomination prospects and electability. In addition, all of the respondents in an exit poll are actual primary voters. With conventional survey techniques, it is necessary to determine which respondents are likely to vote or, in a post-election survey, which respondents actually did vote. Since the level of voter turnout in presidential primary elections is usually quite low (averaging less than one-third of the voting-age population in recent years), the task of identifying actual voters in a cross-sectional survey is quite problematic.

The principal drawback of exit poll data is that the number of questions which can be asked is very limited, and the questions must be kept very simple so that voters can complete the questionnaire in a few minutes. In addition to asking respondents which candidate they voted for in the primary, the Dekalb County Exit Poll included questions asking voters for an overall evaluation of each major candidate in both parties, and for their opinions about which candidates had the best chance of winning the Democratic and Republican nominations, and which candidate in each party had the best chance of winning the November election if nominated by his party. These questions were used to analyze the effects of candidate evaluations, momentum, and electability on voting decisions in the primary. ${ }^{1}$

Path regression analysis was used to test the three models of momentum in a presidential primary. The advantage of path analysis is that the direct

\footnotetext{
${ }^{1}$ See appendix A for the wording of each of these questions, and the coding procedures used in the regression analyses.
} 
and indirect effects of candidate evaluations, viability, and electability on candidate choice can be estimated (Asher 1976). Although the use of a dichotomous dependent variable violates some of the assumptions of regression analysis, the consequences of these violations are generally not severe unless the dependent variable has a very skewed distribution (Aldrich and Cnudde 1975). Since this was not the case, ordinary regression analysis was used to estimate the effects of our independent variables. Discriminant analyses of candidate preference were conducted for both Democratic and Republican primary voters, and the results were very similar to those of the regression analyses. These results are summarized in appendix B.

\section{The Setting: Super Tuesday}

On March 8, 1988, presidential primaries were held in 15 southern and border states, including Georgia, along with several states outside of the South. The brainchild of a group of moderate southern Democratic party leaders, "Super Tuesday" was designed to attract more attention to the South from the presidential candidates and to improve the prospects of a moderate candidate in the Democratic party. The Super Tuesday primaries were the first major campaign event following the New Hampshire primary which was held on February 16. Thus, it should be possible to analyze the impact of the New Hampshire results on Super Tuesday primary voters.

The New Hampshire primary reestablished George Bush as the frontrunner for the Republican presidential nomination following a poor third-place finish in the Iowa precinct caucuses. Pre-Iowa polls had shown Bush with a huge lead over Robert Dole and Pat Robertson in New Hampshire. Following Dole's victory in Iowa, however, the polls and pundits generally portrayed the New Hampshire race as a toss-up between Bush and Dole. Although Bush's eight percentage point margin over Dole was actually much smaller than his earlier lead in the polls, the New Hampshire result was widely interpreted by the news media as a major disappointment and setback to Dole's campaign. In fact, Dole's campaign never recovered from his loss in New Hampshire. On Saturday, March 5, just three days before Super Tuesday, George Bush won a decisive victory over Robert Dole and Pat Robertson in the South Carolina Republican primary. On Super Tuesday, Bush won every Republican primary and virtually clinched the GOP nomination.

Michael Dukakis had been viewed as the early favorite in the New Hampshire Democratic primary because of his position as the governor of neighboring Massachusetts. However, after Dukakis finished third in Iowa behind Richard Gephardt and Paul Simon, there was some question about his ability to maintain his lead in New Hampshire. Dukakis' decisive victory in New Hampshire, combined with a huge financial and organizational advantage over the other Democratic candidates, established him as the Democratic 
frontrunner going into Super Tuesday. Dukakis' position as the Democratic frontrunner was rather tenuous however. His ability to appeal to voters in the South was uncertain, and he faced two additional candidates on Super Tuesday who had not been major factors in Iowa and New Hampshire: Jesse Jackson and Albert Gore, Jr. The outcome of Super Tuesday on the Democratic side was a three-way split in both the popular vote and the delegate race among Dukakis, Jackson, and Gore. However, by finishing first in Texas and Florida and by maintaining his overall lead in delegates, Michael Dukakis probably solidified his position as the frontrunner for the Democratic nomination.

\section{Results}

There was a three-way split among Democratic primary voters in the exit poll, with Jesse Jackson winning $40 \%$ of the vote, followed by Albert Gore, Jr. with $26 \%$ and Michael Dukakis with $24 \%$. The remaining $10 \%$ of the Democratic primary vote was split among Paul Simon (4\%), Richard Gephardt (3\%), Gary Hart (2\%), and uncommitted delegates (1\%). Among Republican primary voters in the exit poll, George Bush received $51 \%$ of the vote compared with $29 \%$ for Robert Dole, $11 \%$ for Pat Robertson, and 7\% for Jack Kemp. Pierre DuPont and Alexander Haig each received 1\% of the vote.

There was a high level of agreement among Democratic and Republican primary voters about which candidate had the best chance of winning each party's nomination. Michael Dukakis was perceived as the frontrunner for the Democratic nomination by $58 \%$ of Democratic primary voters. Trailing Dukakis among Democratic primary voters were Jesse Jackson at $21 \%$, Albert Gore at $14 \%$, and Richard Gephardt at $6 \%$. Dukakis was also seen as the Democratic frontrunner by $64 \%$ of Republican primary voters, followed by Gephardt and Gore with $15 \%$ each, and Jackson with $4 \%$.

George Bush enjoyed an even greater advantage in the GOP contest: $77 \%$ of Democratic primary voters and $80 \%$ of Republican primary voters viewed Bush as the most likely Republican nominee. Twenty percent of Democratic primary voters and $17 \%$ of Republican primary voters picked Robert Dole as the most likely GOP nominee. Only $2 \%$ of Democratic primary.voters and $4 \%$ of Republican primary voters thought that Pat Robertson had the best chance of winning the Republican presidential nomination.

The question of electability also produced a strong consensus across party lines. Dukakis was viewed as the most electable Democratic candidate by $56 \%$ of Democratic primary voters and $63 \%$ of Republican primary voters. Among Democratic voters, Dukakis was followed by Jackson at 21\%, Gore at $16 \%$, and Gephardt at $5 \%$; among Republican voters, $17 \%$ picked both Gore and Gephardt as the most electable Democrat while only $2 \%$ chose Jesse Jackson. 
George Bush was viewed as the most electable Republican candidate by $77 \%$ of Democratic primary voters and by $74 \%$ of Republican primary voters. Among Democratic voters, Robert Dole was viewed as the most electable Republican candidate by $22 \%$ while Jack Kemp and Pat Robertson were each picked by $1 \%$; among Republican voters, Dole trailed Bush at $23 \%$, followed by Robertson at $3 \%$ and Kemp at $1 \%$.

Judgments about candidates' nomination and general election prospects were clearly more than rationalizations of candidate preferences: Democrats and Republicans alike tended to view Michael Dukakis and George Bush as the frontrunners for the Democratic and Republican nominations and as the strongest potential candidates in the general election. This was true despite the fact that, among Democratic primary voters, Robert Dole was evaluated much more positively than George Bush-42\% of Democratic primary voters had a favorable opinion of Dole while only $24 \%$ had a favorable opinion of Bush. The fact that far more voters rated Dukakis and Bush as having the best chance of being nominated and elected than actually voted for either candidate suggests that opinions about the candidates' nomination prospects and electability were strongly influenced by the results of earlier contests and by media interpretations of these results.

How did the widespread perception of Michael Dukakis as the frontrunner for the Democratic nomination affect the candidate preferences of Democratic primary voters on Super Tuesday? In order to answer this question, it is first necessary to control for the influence of race. According to our exit poll, blacks comprised $35 \%$ of the Democratic primary electorate and Jesse Jackson received $97 \%$ of the black vote compared with $2 \%$ for Albert Gore and $1 \%$ for Michael Dukakis. Among whites who voted in the Democratic primary, Gore received 39\% of the vote followed by Dukakis with $38 \%$, Jackson and Simon with $7 \%$ each, Hart with 3\%, and Bruce Babbitt and uncommitted delegates with $1 \%$ each.

Because of the overwhelming support for Jesse Jackson among black voters, our analysis of the effect of momentum on candidate choice will be limited to white voters in the Democratic primary. Among blacks, support for Jesse Jackson was a matter of racial pride. ${ }^{2}$ We will further limit our attention to the two candidates who received the overwhelming majority of the white vote-Michael Dukakis and Albert Gore.

Figure 2 presents the results of the path analysis of candidate preference among white Democratic primary voters. The estimates shown are the standardized regression coefficients or beta weights. These results support the expected utility model of voter decision making. Although candidate evaluations had the strongest direct influence on voting decisions, judgments about

\footnotetext{
${ }^{2} \mathrm{~A}$ separate analysis of the Jackson vote found that race was, by far, the strongest predictor of voting for Jackson followed by evaluations of Jackson. Opinions about Jackson's nomination prospects and electability had no impact on voting decisions.
} 
Figure 2

Path Analysis of Candidate Choice in Democratic Primary $(N=98)$

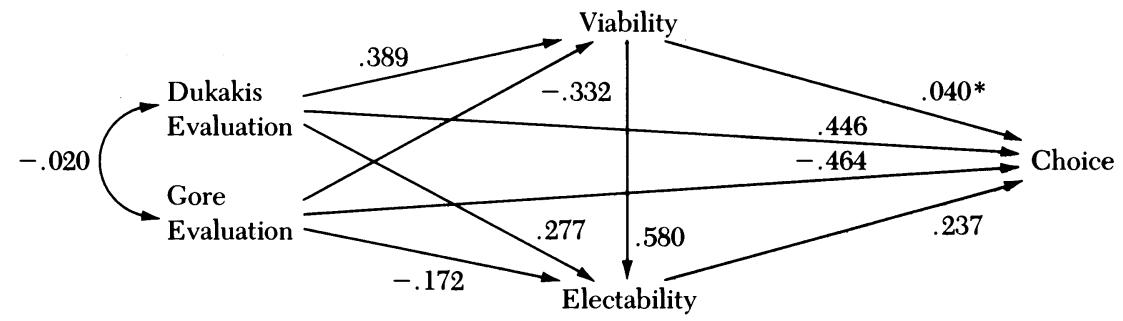

Estimated Effects of Independent Variables

$\begin{array}{lcc} & \text { Direct } & \text { Indirect } \\ \text { Dukakis evaluation } & .446 & .135 \\ \text { Gore evaluation } & -.464 & -.100 \\ \text { Viability } & .040 & .137 \\ \text { Electability } & .237 & -\end{array}$

Note: Estimates shown are standardized regression coefficients. Double-headed arrow represents correlation coefficient. Estimate marked with asterisk is not statistically significant. All other estimates are significant at .05 level or greater.

which candidate had the best chance of winning the November election also had a substantial direct impact on candidate choice. Based on the estimated unstandardized regression coefficient for electability, perceiving Michael Dukakis as the most electable Democratic candidate increased the probability of voting for Dukakis over Albert Gore by about 27 percentage points compared with perceiving Gore as the most electable Democratic candidate. By multiplying the estimated unstandardized regression coefficient for relative electability $(.135)$ by the mean electability score among white Democratic primary voters $(+.41)$, we can estimate that perceptions of electability increased Dukakis' overall vote by about 5.5 percentage points over what he would have received if he and Gore had been perceived as equally electable.

Opinions about the candidates' viability apparently had little or no direct influence on voting decisions, but did strongly influence opinions about electability. The estimated unstandardized regression coefficient for the effect of viability on electability (.601) indicates that perceiving either Michael Dukakis or Albert Gore as the most likely Democratic nominee increased the likelihood of perceiving the same candidate as the most electable Democrat by about 60 percentage points.

There is clear evidence of wishful thinking among Democratic primary voters: voters tended to perceive the candidate they liked best as having the best chance of being nominated and elected. However, perceptions of the 
Figure 3

Path Analysis of Candidate Choice in Republican Primary $(N=128)$

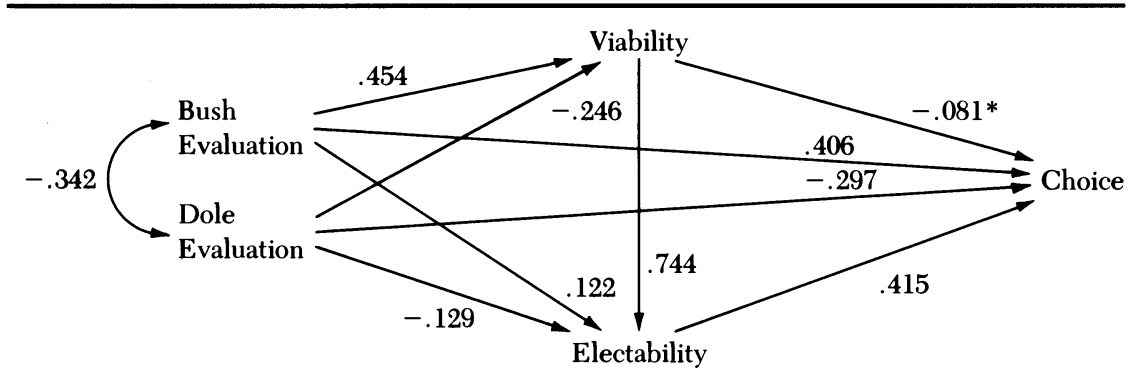

Estimated Effects of Independent Variables

\begin{tabular}{lcc}
\multicolumn{3}{c}{ Estimated Effects of Independent Variables } \\
& Direct & Indirect \\
Bush evaluation & .406 & .154 \\
Dole evaluation & -.297 & -.110 \\
Viability & -.081 & .309 \\
Electability & .415 & -
\end{tabular}

Note: Estimates shown are standardized regression coefficients. Double-headed arrow represents correlation coefficient. Estimate marked with asterisk is not significant at .05 level. All other estimates are statistically significant at .05 level or greater.

candidates' nomination prospects were the most important factor influencing opinions about electability, and evaluations of Dukakis and Gore only explained about one-fourth of the variance in voters' opinions about which candidate was most likely to receive the Democratic nomination.

Among Republican primary voters in our exit poll, George Bush and Robert Dole received a combined total of $80 \%$ of the vote. We will therefore limit our analysis of Republican primary voters to those choosing one of these two candidates. Figure 3 presents the results of the path analysis of candidate preference among Republican primary voters. Once again, the results are consistent with the expected utility model of voter decision making. Among Republican primary voters, moreover, opinions about the candidates' electability had a stronger direct impact on voting decisions than evaluations of either of the candidates. Based on the estimated unstandardized regression coefficient for electability, perceiving George Bush as the most electable Republican candidate increased the probability of voting for Bush over Robert Dole by about 48 percentage points compared with perceiving Dole as the most electable Republican candidate. By multiplying the estimated unstandardized regression coefficient for relative electability (.238) by the mean electability score among Republican primary voters $(+.55)$, we can estimate that perceptions of electability increased Bush's 
overall vote by about 13.1 percentage points over what he would have received if he and Dole had been perceived as equally electable.

Perceptions of the candidates' nomination prospects had no direct impact on voting decisions (in fact, the estimate for this path is in the wrong direction), but did strongly influence opinions about electability. The estimated unstandardized regression coefficient for the effect of viability on electability (.812) indicates that perceiving either George Bush or Robert Dole as the most likely Republican nominee increased the likelihood of perceiving the same candidate as the most electable Republican by about 81 percentage points. Wishful thinking is again evident although evaluations of Bush and Dole had very little direct bearing on opinions regarding electability and only explained about one-third of the variance in judgments about which candidate was most likely to win the Republican nomination.

An alternative explanation for these findings is that they reflect post-decisional rationalization-after voters decide which candidate to support, they may rationalize that decision by assuming that their preferred candidate is the one most likely to win the nomination or the general election or both. However, the evidence from our exit poll appears to be inconsistent with this hypothesis. If voters rationalized their candidate preference by assuming that their preferred candidate was most likely to win the nomination and the general election, then candidate preference should have a direct influence on perceptions of the candidates' nomination prospects, after controlling for perceptions of electability. However, when perceptions of nomination prospects were regressed on candidate choice and perceptions of electability, vote choice had almost no impact on opinions regarding the candidates' nomination prospects. If voters' candidate preferences only affected their judgments about electability, then opinions about the candidates' nomination prospects should have no impact on voting decisions with electability left out of the analysis. However, opinions about the candidates' nomination prospects did have substantial and statistically significant effects on candidate preference in both parties when electability was excluded from the regression equation. Thus, if we can assume that opinions about candidates' nomination prospects are causally prior to opinions about their electability, the data from the exit poll are inconsistent with the post-decisional rationalization hyothesis.

\section{Discussion AND Conclusions}

Momentum had a major influence on the voting decisions of Republican and white Democratic primary voters in our exit poll. By winning the New Hampshire primary, George Bush and Michael Dukakis established themselves as the frontrunners for the Republican and Democratic presidential nominations in the minds of Super Tuesday primary voters. This perception was important primarily because it caused voters to view Bush and Dukakis 
as the most electable candidates in their respective parties. In choosing a candidate for their party's nomination, Republican and Democratic primary voters weighed electability in addition to their general evaluations of the candidates seeking the nomination.

Although momentum was an important factor in both primaries, it probably was not the determining factor in the outcome of either. In the Republican primary, momentum reinforced the advantage in voter evaluations which George Bush enjoyed over Robert Dole. Without momentum, however, Bush's margin over Dole would probably have been substantially smaller. In the Democratic primary, the candidate with momentum, Michael Dukakis, finished third behind Jesse Jackson and Albert Gore. Dukakis' momentum was not enough to overcome Jackson's strong appeal to black voters or Gore's emphasis on ideological moderation and his appeal to regional loyalty. Without momentum, however, it is likely that Dukakis would have fared very poorly on Super Tuesday.

The findings presented in this paper do not support the idea that momentum is especially important when the candidates seeking the nomination are not well known. In our exit poll, the impact of momentum was greater in the Republican primary than in the Democratic primary, despite the fact that the two major Republican candidates-Bush and Dole-were very familiar national political figures, while both Michael Dukakis and Albert Gore were almost unknown at the start of the campaign. The importance of momentum in the Republican race may have reflected the absence of any clear issue or ideological differences between the two leading contenders. Both Bush and Dole campaigned in the South as conservatives who strongly supported Ronald Reagan's policies. The only controversy in the campaign was over which candidate had been more effective in supporting Reagan. Lacking any other basis on which to distinguish between Bush and Dole, Republican primary voters relied heavily on their judgment about which candidate had the best chance to win in November. That judgment was, in turn, strongly influenced by the perception of George Bush as the clear frontrunner for the GOP nomination.

To a considerable extent, the voters in our exit poll acted as rational utility maximizers. Anticipating the upcoming general election, they weighed electability along with their evaluations of the candidates in deciding whom to support in the primary. This finding may provide some comfort to those concerned about the effects of recent nominating reforms on the ability of the parties to choose candidates with broad electoral appeal (Polsby 1983). However, students of the nominating process may find it somewhat disturbing that primary voters base their evaluation of a candidate's electability almost exclusively on his performance in earlier primaries and caucuses. On Super Tuesday, George Bush and Michael Dukakis were seen as the most electable Republican and Democratic candidates largely because of their victories in the New Hampshire primary three weeks earlier. Many political analysts 
and professional politicians did not share this view, however. Several national polls conducted before Super Tuesday indicated that Robert Dole would be a stronger Republican nominee than George Bush because of his greater appeal to independent voters and Democrats. At the same time, many southern Democratic party leaders and elected officials felt that Albert Gore would be a stronger candidate than Michael Dukakis because of his southern roots and moderate image. Judging a candidate's ability to win a general election on the basis of his success in party primaries and caucuses can be very misleading. Primaries and caucuses only test a candidate's appeal among voters who identify with the candidate's party. In order to win a presidential election, however, a Democratic or Republican candidate must also appeal to independents and supporters of the opposing party. The candidate with momentum in March is not necessarily the candidate with the best chance of winning in November.

Much more research is needed on the role of momentum and electability in presidential primary elections. It would be hazardous to attempt to generalize from the findings of an exit poll conducted in a single county in one early primary contest. If possible, future studies should employ more sensitive measures of attitudes about candidates' nomination and general election prospects instead of asking voters which candidate is most likely to win. By obtaining probability or quasi-probability estimates of candidates' chances, it should be possible to test more sophisticated models of voter decision making (Abramowitz and Stone 1984, chap. 6). Future studies should also explore the effects of campaign context and timing on voter decision making. The relationship between momentum and voter perceptions of viability and electability may change over time: the results of recent primaries may have less impact on perceptions of viability and electability in the later stages of the nominating campaign. Finally, research is needed on the role of media coverage in shaping voters' evaluations of candidate performance in the primaries and caucuses. Given the role that perceptions of momentum play in voter decision making, the power of the media to set expectations regarding a candidate's performance and to evaluate performance in relation to these expectations may be crucial in determining a candidate's success in the nominating campaign.

Manuscript submitted 10 August 1988

Final version received 3 April 1989

APPENDIX A

Description of Sampling Procedure, Question Wording, and Coding Procedures used in Exit Poll

A stratified random sample of 13 precincts in Dekalb County was used to conduct the exit poll. Because of the high level of racial polarization ex- 
pected in the Democratic primary, all of the precincts in the county were first stratified according to racial composition. Within each racial grouping, a random sample of precincts was selected. Questionnaires were distributed and collected by undergraduate students at Emory University. Each student was assigned a specific precinct and two-hour time period and instructed to collect as many questionnaires as possible from voters leaving the polling place. Time periods were distributed throughout the day, but concentrated mainly during periods of heavy voting (early morning, midday, late afternoon, and early evening).

The results of the exit poll were very close to the actual results of the primary election in Dekalb County. In the county, $61 \%$ of the voters chose to participate in the Democratic primary while $39 \%$ chose to participate in the Republican primary; in the exit poll, $62 \%$ of the respondents reported voting in the Democratic primary while $38 \%$ reported voting in the Republican primary. In the Democratic primary, Jesse Jackson received $46 \%$ of the vote compared with $24 \%$ for Albert Gore, $23 \%$ for Michael Dukakis, $4 \%$ for Richard Gephardt, $3 \%$ for Paul Simon, and 1\% each for Gary Hart and uncommitted delegates; in the exit poll, $40 \%$ of respondents reported voting for Jesse Jackson compared with 26\% for Albert Gore, 24\% for Michael Dukakis, $4 \%$ for Paul Simon, 3\% for Richard Gephardt, 2\% for Gary Hart, and $1 \%$ for uncommitted delegates. In the Republican primary, George Bush received $54 \%$ of the vote compared with $27 \%$ for Robert Dole, $12 \%$ for Pat Robertson, and $7 \%$ for Jack Kemp; in the exit poll, $51 \%$ of respondents reported voting for George Bush with $29 \%$ for Robert Dole, $11 \%$ for Pat Robertson, and 7\% for Jack Kemp.

In the exit poll, candidate preference was measured by the following question: "Which candidate did you vote for in the primary?" Respondents were given a checklist of all Democratic and Republican candidates.

Opinions about the candidates' nomination prospects were measured by the following question: "Regardless of whom you support, which Democratic and Republican candidate do you think has the best chance of winning his party's nomination?" Respondents were given checklists of the following candidates: Dukakis, Gephardt, Gore, Hart, Jackson, and Simon for the Democrats; Bush, Dole, Kemp, and Robertson for the Republicans.

Opinions about the candidates' general election chances were measured by the following question: "Regardless of whom you support, which Democratic and Republican candidate do you think has the best chance of winning the general election in November if he is nominated by his party?" The choices were Dukakis, Gephardt, Gore, Hart, Jackson, and Simon for the Democrats, and Bush, Dole, Kemp, and Robertson for the Republicans.

Overall evaluations of the candidates were measured by the following question: "What is your overall opinion of each of the following political leaders?" Respondents were asked for their opinions of Bush, Dole, Dukakis, 
Gephardt, Gore, Jackson, and Robertson. The response alternatives were "very favorable," "somewhat favorable," "neutral," "somewhat unfavorable," and "very unfavorable."

In the path analysis of Democratic primary voters, the vote choice question was scored as $+\mathbf{1}$ for a Dukakis vote and $\mathbf{0}$ for a Gore vote. In the analysis of Republican primary voters, a Bush vote was scored as +1 and a Dole vote was scored as $\mathbf{0 .}$

Candidate evaluations were scored from -2 (very unfavorable) to +2 (very favorable), with a neutral opinion scored as a 0 . Among Democratic primary voters, opinions about the candidates' nomination prospects and electability were scored as follows: +1 if Dukakis was viewed as having the best chance, -1 if Gore was viewed as having the best chance, and 0 if some other candidate was viewed as having the best chance.

Among Republican primary voters, opinions about the candidates' nomination prospects and electability were scored as follows: +1 if Bush was viewed as having the best chance, -1 if Dole was viewed as having the best chance, and 0 if some other candidate was viewed as having the best chance.

\section{APPENDiX B}

Results of Discriminant Analyses of Candidate Choice Among Democratic and Republican Primary Voters

\begin{tabular}{lcc}
\hline Variable & $\begin{array}{c}\text { Democrats } \\
(N=98)\end{array}$ & $\begin{array}{c}\text { Republicans } \\
(N=128)\end{array}$ \\
\hline Candidate 1 evaluation & .791 & .637 \\
Candidate 2 evaluation & -.838 & -.526 \\
Electability & .386 & .637 \\
Viability & .072 & -.141 \\
Chi-Squared & 112.7 & 156.2 \\
Significance & $<.001$ & $<.001$ \\
Percentage of cases & & 96.1 \\
predicted correctly & 92.9 & 96.1 \\
\hline
\end{tabular}

Note: Entries shown are standardized discriminant function coefficients. For Democrats, candidate $1=$ Dukakis, candidate $2=$ Gore; for Republicans, candidate $1=B u s h$, candidate 2 = Dole. Based on Democrats voting for Dukakis or Gore, Republicans voting for Bush or Dole.

\section{REFERENCES}

Abramowitz, Alan I. 1987. "Candidate Choice before the Convention: The Democrats in 1984." Political Behavior 9:49-61.

Abramowitz, Alan I., and Stone, Walter J. 1984. Nomination Politics. New York: Praeger. Aldrich, John H. 1980. Before the Convention. Chicago: University of Chicago Press. Aldrich, John H., and Cnudde, Charles. 1975. "Probing the Bounds of Conventional Wisdom: 
A Comparison of Regression, Probit, and Discriminant Analysis." American Journal of Political Science 19:571-608.

Asher, Herbert B. 1976. Causal Modeling. Beverly Hills, CA: Sage Publications.

Bartels, Larry M. 1985. "Expectations and Preferences in Presidential Nominating Campaigns." American Political Science Review 79:804-15.

Bartels, Larry M. 1987. "Candidate Choice and the Dynamics of the Presidential Nominating Process." American Journal of Political Science 31: 1-30.

Brady, Henry E., and Johnston, Richard. 1987. "What's the Primary Message: Horse Race or Issue Journalism?" In Media and Momentum, eds. Gary R. Orren and Nelson W. Polsby. Chatham, NJ: Chatham House.

Markus, Gregory B. 1982. "Political Attitudes during an Election Year: A Report on the $\mathbf{1 9 8 0}$ NES Panel Study." American Political Science Review 76:538-60.

Markus, Gregory B., and Converse, Philip E. 1979. "A Dynamic Simultaneous Equation Model of Electoral Choice." American Political Science Review 73:1055-70.

Orren, Gary R., and Polsby, Nelson W. 1987. Media and Momentum. Chatham, NJ: Chatham House.

Polsby, Nelson W. 1983. Consequences of Party Reform. New York: Oxford University Press.

Alan I. Abramowitz is professor of political science, Emory University, Atlanta, GA 30322. 